\title{
Manligt och kvinnligt på familjesidan
}

\section{Av Gunilla Byrman}

\author{
Länk till presentation av Gunilla Byrman
}

I allt slags medieutbud finns genuskonstruktioner som kan innehålla asymmetrier som vi inte märker vid en hastig genomläsning men som blir tydliga vid en analys. I tidningstexter återspeglas samtiden. Därför är den världsbild som tidningarna återger ett bra sätt att se huvudströmningarna i kulturen.

Syftet med denna undersökning är att studera hyllningstexter på dagstidningarnas familjesida. Det görs i ett historiskt perspektiv för att se hur könsrollernas innehåll i texterna förändras och hur genrer och textmönster utvecklas över tid. Följande forskningsfrågor ställs till materialet, som består av dagstidningar, både lokala och rikstäckande:

1. Vem hyllas på familjesidan?

2. Hur skildras kvinnor och män i texterna?

3. Vilka textgenrer och textmönster finns?

Familjesidan innehåller både redaktionellt material, dvs. hyllningstexter och lättare material skrivet av journalister, och icke-redaktionellt material som betalannonser och hyllningstexter skrivna av personer som vill hylla någon de känner.

Studien bedrivs i ett genusperspektiv med den kritiska diskursanalysen som teoretisk ram (Byrman \& Hultén 2003). Analysen fokuserar på idéinnehåll, språk och kontext. Den kritiska diskursanalysens premisser är att sociala identiteter, relationer, kunskaps- och värdesystem skapas och bevaras av diskursiva praktiker (Fairclough 1992, Hellspong \& Ledin 1997). Tidningar är en inflytelserik diskurs och har en ideologiproducerande roll då de bidrar till att konstruera innebörder och betydelser, och familjesidans roll ska inte underskattas i detta samanhang. Det traditionella genussystemets innehåll härrör från en äldre maktfördelning, där familjen var den ekonomiska grundenheten i samhället (jfr Hirdman 1988, 1998). Männen hade makten över privategendom, och de innehade också den politiska makten, vilket innebar att de hade beslutanderätt över kvinnor. Av tradition definierades kvinnor och kvinnors verksamheter därmed av män. Dessa maktstrukturer har över tid förändrats; män och kvinnor har numera enligt lagen samma rättigheter och skyldigheter. Men gamla idéer om hur kvinnor och män är eller bör vara har en tendens att dröja sig kvar i människors medvetande, och mer eller mindre omedvetet manifesterar sig i språket.

Jag studerar vilka språkliga strategier hyllningstexter innehåller, och hur kvinnor och män presenteras i texterna för att passa in i det harmoniska, semiotiska rum som familjesidan är (jfr Byrman 2002).

Innehållsligt kan genrerna på familjesidan i grova drag indelas i:

1. Hyllningar i vid bemärkelse eller texter om personer som någon vill uppmärksamma: födda, adoption, uppvaktning önskas (alt. undanbedes), födelsedagar, namnsdagar, förlovningar (förlovningsbild), trolovning, lysning, vigsel, bröllop (brudbild), berömvärda insatser, examen, jubileum, konfirmation, skolavslutning, dödsannons, dödsfall, nekrologer, begravningsreferat, urnsättning, in memoriam.

2. Tack för hyllningar, fester, hjälp, berömvärda insatser etc. 
Hyllningstexter par excellence är texter till födelsedagar och vid dödsfall. Här ska jag uppehålla mig vid tre textslag: födelsedagsnotiser, dödsfallsnotiser och nekrologer (minnesord) från 1946 och 2004. Dessa texter är likartade till form och innehåll, och de framstår som ett slags biografier i kortform.

\section{Några resultat}

Den första frågan: Vem hyllas på familjesidan? är enkel att besvara. Det är prenumeranter och deras närstående, men också de personer som familjeredaktionen av någon anledning anser ha ett intressant levnadsöde eller ett stort allmänintresse. Därför finns det en blandning av kändisar och doldisar på familjesidan.

Tabell. Texter på familjesidorna i Dagens Nyheter, Sydsvenska Dagbladet och Smålandsposten 10 dagar sommaren 2004. kön $(\mathbf{m}=$ män och $\mathbf{k}=$ kvinnor $), r=$ redaktionell text och ir $=$ icke-redaktionell text.

\begin{tabular}{|c|c|c|c|c|c|c|c|}
\hline Textsort & DN-k & DN-m & SDS-k & SDS-m & Smp-k & Smp-m & Totalt \\
\hline Födda & 69 & 65 & 64 & 58 & 16 & 15 & 287 \\
\hline Adoption & - & - & 2 & - & - & - & 2 \\
\hline Dop & 1 & - & - & - & - & - & 1 \\
\hline \multicolumn{8}{|l|}{ Konfirmation } \\
\hline Föd.dag (r) & 2 & 8 & 8 & 8 & 4 & 9 & 39 \\
\hline Föd.dag (ir) & 59 & 46 & 24 & 52 & 12 & 13 & 206 \\
\hline Grattisbild & 6 & 12 & 109 & 152 & 116 & 107 & 502 \\
\hline Förlovning & 29 & 29 & 22 & 22 & 19 & 19 & 140 \\
\hline \multicolumn{8}{|l|}{ Trolovning } \\
\hline Lysning & 1 & 1 & 1 & 1 & - & - & 4 \\
\hline Vigsel & 20 & 20 & 16 & 16 & 23 & 23 & 118 \\
\hline Bröllop, bild & 26 & 26 & 44 & 44 & 32 & 32 & 204 \\
\hline \multicolumn{8}{|l|}{ Brudbild } \\
\hline Bröllopsjub. & 31 & 31 & 40 & 40 & 6 & 6 & 154 \\
\hline \multicolumn{8}{|l|}{ Övriga jub. } \\
\hline \multicolumn{8}{|l|}{ Skolavslutn. } \\
\hline \multicolumn{8}{|l|}{ Examen } \\
\hline \multicolumn{8}{|l|}{ Avlidna } \\
\hline Dödsannons & 146 & 139 & 76 & 56 & 38 & 30 & 485 \\
\hline Dödsfall (r) & 1 & 2 & 7 & 20 & 10 & 11 & 51 \\
\hline Minnesord (ir) & 4 & 14 & 3 & 11 & 2 & 2 & 36 \\
\hline \multicolumn{8}{|l|}{ Begrav.ref. } \\
\hline \multicolumn{8}{|l|}{ Urnsättning } \\
\hline In memoriam & 8 & 7 & 9 & 9 & 3 & 3 & 39 \\
\hline Uppvaktning önskas & - & - & 16 & 13 & 4 & 3 & 36 \\
\hline Uppvaktning undanbedes & - & - & 48 & 64 & 20 & 43 & 175 \\
\hline Tack & & 6 & 15 & 11 & 12 & 13 & 57 \\
\hline Namnändr. & & & & & 1 & & 1 \\
\hline Berömvärda insatser & 5 & 3 & - & 1 & - & - & 9 \\
\hline Totalt & & & & & & & 2546 \\
\hline Kvinnor totalt & 408 & & 504 & & 318 & & $1230(48 \%)$ \\
\hline Män totalt & & 409 & & 578 & & 329 & $1316(52 \%)$ \\
\hline
\end{tabular}


Jag har gjort en kvantitativ studie där jag undersökt Dagens Nyheter, Sydsvenska Dagbladet och Smålandsposten.[1] Tabellen visar att det finns många olika texter på familjesidan. De genrer som finns kan indelas i notis (betalannons eller gratisannons, båda med eller utan bild), artikel (som vanligen är hyllningstexter av olika slag), intervju och reportage.

Tabellen ger ingen uttömmande inventering av alla texter som förekommer på familjesidan, men det gemensamma är att de flesta texterna där berör händelser i privatlivet, från vaggan till graven och några även därefter, t.ex. begravningsreferat, urnsättning och in memoriam.

Könsfördelningen mellan dem som hyllas i texterna ser ganska jämn ut; det är $52 \%$ män och 48 \% kvinnor.[2] Hade jag mätt i spaltmeter hade skillnaden blivit större eftersom det är hyllningarna till män som får störst utrymme. De stora texterna - reportage, intervju eller artikel (nekrolog) - skrivs ofta om män och av män. Så har det alltid varit, förre i högre grad än nu. Är då det att männen tillåts ta mest plats på denna sida, ett spegling av den kvinnliga underordning som fortfarande finns i samhället? Detta kan vi fundera över, och jag kommer att återkomma till denna fråga senare.

Om kvantiteten av texter säger något om vad som är de viktigaste personhändelserna så verkar det av tabellen att döma vara i nu nämnd ordning: födelsedagar, dödsfall, barns födelse och bröllop. Det verkar rimligt att anta att det förhåller sig så. Annat som också förefaller viktigt är bröllopsjubileum, och något mer förvånande mängden annonser under "Uppvaktning undanbedes". Det är framför allt män som undanber sig födelsedagsfirande.

\section{Analystexter från 1946 och 2004}

Nedan följer några typiska exempel på texter från 1946 och 2004. Jag börjar med några födelsedagshyllningar till 50-åringar år 1946.

\section{Födelsedagsnotiser 1946}

- Femtio år fyller den 22 januari fru S i g n e $\mathrm{N}$ o r d h o l m , f. Charpentier, maka till kyrkoherde Ragnar Nordholm, Limhamn.

Bredvid sin största uppgift som maka och mor i det gästfria prästhemmet, där hon alltid är en lika hjärtlig som omtänksam värdinna, har hon också tagit del i församlingsarbetet.

Genom sitt enkla och flärdfria väsen och sin rättframma hjärtlighet har hon förvärvat sig en stor fond av uppriktig aktning och tillgivenhet både i och utanför församlingen. (SDS 22.1.1946) (Ansiktsbild)

- Femtio år fyller den 23 januari undervisningsrådet G u s t a f S i v g å r d, Stockholm.

Han är född i Kalmar och blev student där 1915. Följande år avlade han folkskollärareexamen, blev fil. kand. 1920 och fil. lic. 1928. Åren 1917-1933 var han folkskollärare i Kalmar. Han var 1932-1942 folkskolinspektör i Sydsmålands mellersta inspektionsområde. Undervisningsråd blev han 1942. (SDS 22.1.1946) (Ansiktsbild)

Det är stor skillnad på notiserna, både språkligt och innehållsligt. I notisen om kvinnan är det hennes roll i privatsfären som framhålls mest, och det är inre egenskaper som prisas. Det finns också många värderande fraser: "en lika hjärtlig som omtänksam värdinna", "sitt enkla och flärdfria väsen och sin rättframma hjärtlighet" och "stor fond av uppriktig aktning och tillgivenhet". Så ser hyllningstexter till kvinnor ofta ut vid denna tid, dvs. de fokuserar på hur kvinnorna är.

Notisen om mannen domineras helt av hans akademiska karriär och yrkeskarriären, m.a.o. hans liv i den offentliga sfären och vad han är. Så ser typiska hyllningar till män ut vid denna tid. Läsaren får inte veta något om jubilarens relation till andra, t.ex. om han är gift eller har barn. Hyllningen ser mest ut som ett utdrag ur en meritförteckning och inga egenskaper nämns. Vi ser att den gamla uppdelningen mellan känsla (kvinnligt) och förnuft 
(manligt) är närvarande i texterna ovan.

Här ska tilläggas att dessa notiser är skrivna av en journalist på redaktionen. Så är det oftast inte numera utan istället låter redaktionerna prenumeranterna lämna material till notiserna som sedan bara lätt redigeras innan de publiceras. Nedanstående exempel är hämtat från Sydsvenska Dagbladets familjesida 20 augusti i år.

\section{Födelsedagsnotiser 2004}

\section{0 år}

Frank Howegård, Malmö, den 20 augusti. Han är född i Nybro men flyttade efter yrkesutbildning till Göteborg 1937 där han drev en målerifirma. 1940 flyttade han till Malmö där han gifte sig med sin fru Daga. De fick en son 1945.

Sedan pensioneringen 1979 ägnar han sig bland annat åt att teckna och måla tavlor. Frank Howegård har dessutom alltid varit idrottsintresserad och var aktiv fotbollsspelare när han var ung. Idag blir det mest simning. Intresset för musik är också stort, och under många år spelade han trombon i blåsorkester.

\section{0 år}

Förre valsare Walter Pedersen, Malmö, den 21 augusti. Han är född i Svolvær vid Lofoten. Han arbetade i Jesseheim och Oslo och seglade som matros runt jorden innan han kom till Malmö 1956. Här gifte han sig och fick fyra barn, och han arbetade på Kockums och Tankmobil innan pensioneringen 1989. Idag njuter han av livet och sina nio barnbarn.

Konstnären Margaretha Rindestam, Malmö, den 21 augusti. Hon är född i Dalby och har tidigare arbetat som försäljare i herrekipering på AB E Ohlsson, Cason och NK i Malmö och sex år på Gulins i Göteborg.

Hon målar i olja och akvarell och har ställt ut i Malmö, Trelleborg, Göteborg, Stockholm och Toscana i Italien.

Margaretha Rindestam tycker om att göra utflykter i naturen tillsammans med sin sambo Stig som hon firar 25 år tillsammans med i samband med sin födelsedag.

\section{5 år}

Adem Lapastica, Malmö, den 20 augusti. Han är född i Marvci, Kosovo. Han kom till Sverige 1995 och har varit verksam som vakt.

\section{0 år}

Lennart Sjöström, Furulund, den 20 augusti. Han är född i Kävlinge och har bland annat jobbat på Tetra Pak och Mab \& Mya. Idag är han förtidspensionär och ägnar tiden åt att läsa böcker, omkring hundra stycken om året, och lyssna på musik.

\section{0 år}

Personlig assistent Gunilla Andersson, Malmö, den 21 augusti. Hon jobbar på Malmö kommun.

Elisabeth Barrdahl, Lund, den 20 augusti.

Auktoriserade revisorn Anita Dumky, Bunkeflostrand, den 20 augusti. Hon är född i Karlskrona och arbetar på Öhrlings Pricewaterhouse Coopers.

Baltzar Edberg, Malmö, den 21 augusti, född i Uddevalla. Han arbetade som fritidsledare på en motorfritidsgård i Malmö tills han skadades för femton år sedan. Idag är han pensionär men är mycket aktiv och är bland annat med i styrelsen för föreningen Hjärnkrafts Malmöavdelning.

Baltzar Edberg lyssnar på musik, helst 60-tals rock'n'roll, sjunger i körer, tävlingsskjuter med gevär, bowlar och reser gärna. Han tränar dessutom målmedvetet nästan dagligen på aktivitetscentret Fröet. (SDS 20.8.2004) 
Texterna om män är fler, längre och innehållsrikare, och därför framstår personer som omtalas i dem som intressantare. I den första om Frank Howegård får vi reda på en hel del både om hans karriär och privatliv, exempelvis att han har utbildat sig i Göteborg, drivit målerifirma, är gift, har en son och att han ägnat sig åt teckning samt är idrotts- och musikintresserad. Notisen kan jämföras med den relativt långa texten om Margaretha Rindestam, där vi också får reda på en del men inte lika mycket, exempelvis att hon jobbat i olika herrekiperingsaffärer, att hon målar och har haft utställningar, att hon tycker om att göra utflykter med sin sambo.

Det är vanligare att sådana här notiser om kvinnor är korta, och ser ut som texterna om de kvinnliga 50-åringarna ovan: "Personlig assistent Gunilla Andersson, Malmö, den 21 augusti. Hon jobbar på Malmö kommun" och "Elisabeth Barrdahl, Lund, den 20 augusti". Dessa korta texter känns en smula innehållslösa i jämförelse med längre notiser.

Jubilarerna själva eller närstående har bidragit med faktauppgifter. Notiserna är rätt stereotypa. En anledningen till detta är att tidningarna oftast har ett formulär som uppgiftslämnaren fyller i, och detta ger textmönstret. I Sydsvenska Dagbladets textformulär ska jubilarernas namn, adress, födelsedatum, födelseort, titel eller yrke, arbetsplats och bakgrund uppges, och följande frågor besvaras: Vad gör du nu? Intressen eller hobby? Vad vill du mer berätta om dig själv?

Av formuläret och texterna i tidningarna framgår att vissa uppgifter är obligatoriska, som namn, ålder och hemort. Beroende på hur fylligt jubilaren skriver skapar familjeredaktören sedan en kortare eller längre notis med utgångspunkt i de inlämnade uppgifterna. De kvinnliga jubilarerna eller närstående till dem lämnar uppenbarligen inte lika många och fylliga uppgifter till notiserna som män eller deras närstående. Kvinnorna vill synas men bara lite grann. Vad det beror på kan diskuteras. Kanske lär sig kvinnor av den rådande samhällsordningen att det är passande att märkas men inte för mycket om man är kvinna.

Familjesidan är som tidigare nämnts en arena där redaktionella och icke-redaktionella texter samt yrkesskribenter och lekmän samsas om utrymmet, och just i dessa notiser har båda bidragit med textmaterial. Här har den diskursiva praktiken ändrat sig över tid. För tidningen är det en plikt att publicera men inte längre en journalistisk uppgift, som det var t.ex. på 1940-talet.

Vi ska nu övergå till att se hur två dödsfallsnotiser, båda från 22 januari 1946 gestaltar sig.

\section{Dödsfallsnotiser 1946}

C. N. Carlsson †. Förre fabrikören Carl Niklas Carlsson, Visby, har avlidit 84 år gammal. Han var född i Lojsta på Gotland och vistades från 20-årsåldern under 30 år i Amerika och på Nya Zeeland, där han var verksam som byggmästare. Efter återkomsten till Gotland innehade han i många år ett gjuteri och en snickerifabrik. På senare år levde han för sig själv på Södervärn, där han fördjupade sig i studier och skaffade sig betydande kunskaper på skilda bildningsområden. Han var mycket originell och torde i sin religiösa tro stått buddhismen nära. Närmast sörjes han av en syster i Lojsta. (SDS 22.1.1946)

Anna Hjärne †. Fru Anna Hjärne, maka till regeringsrådet Karl-Gustaf Hjärne, Djursholm, avled i söndags.

Den avlidna var född i Leksand 1892, dotter till hemmansägaren Skräddar Lars Larsson och hans maka, född Andersdotter. Närmast efterlämnar hon förutom maken en son och tre döttrar samt syskon. (SDS 22.1.1946)

Strukturen i dessa dödsfallsnotiser påminner om den som finns i födelsedagsnotiserna från 1946. Notisen om mannen är längre och handlar om hans yrkesliv men också hans privatliv, såsom att han levde "för sig själv på Södervärn", en stadsdel i Malmö. Vi kan notera att det finns värderande omdömen om honom: "skaffade sig betydande kunskaper på skilda bildningsområden. Han var mycket originell och torde i sin religiösa tro stått 
buddhismen nära". Det sistnämnda var vid denna tid förmodligen så ovanligt att det var värt ett omnämnande.

Notisen om kvinnan omtalar enbart civilstånd, makens namn och titel, hemort, i detta fall Djursholm, födelseort och släktskapsförhållanden till de efterlämnade. I notisen finns ingen beskrivning av hennes verksamhet eller egenskaper. Förmodligen är uppgifterna i texten lånade från en Stockholmstidning. Textlån mellan familjeredaktioner är legio och sker rutinmässigt. Här har personernas hemort påverkat texternas längd och hur texterna utformats. Det vill säga notisen om mannen har lokal anknytning och är därför längre och utförligare, medan den om kvinnan inte har det och därför är kort och saklig. Men faktum kvarstår: Det är den kortare texten som skrivs om kvinnan.

\section{Dödsfallsnotiser 2000-talet}

Nedan presenteras två dödsfallsnotiser från 2003 och 2004.

\section{Värner Råsne har avlidit}

Folkskollärare Värner Råsne, Malmö, har avlidit i en ålder av 92 år.

Han var född i Stenbrohult 1912. Värner Råsne avlade folkskollärareexamen i Växjö 1936 och tjänstgjorde i sin hemförsamling åren 1937-1939 och sedan 1940 i Malmöskolor.

Hans närmaste anhöriga är makan Annalisa, dottern Evalisa, Älmhult, och sonen Sven, Malmö, med familjer samt syskon. (Smp 18.8.2004)

Denna notis följer ett känt och gammalt mönster med titel, namn, hemort, ålder. Därefter en kort levnadsbeskrivning i form av en meritförteckning och slutligen anges namnen på de anhöriga. Texten är förmodligen redaktionellt skriven. Eventuellt är detta en återbrukstext från en publicerad födelsedagstext med anledning av mannens 90-årsdag, som inte är så långt tillbaka i tiden. Det är brukligt att fräscha upp och återanvända texter på detta sätt på familjeredaktionerna.

Den andra notisen är över en kvinna.

Kerstin Söderström, Knislinge

Kerstin Söderström, 59 år, Knislinge, har avlidit. Hennes närmaste är maken Ove, barn, barnbarn, mor och syskon.

Hon var född i Vikmanshyttan i Dalarna och kom tidigt till Uppsala. Därifrån flyttade hon till Skåne och Eslöv 1979. Sedan till Bara och därefter till Malmö där hon drev Lilla Caféet på Stora Nygatan. Från Malmö flyttade Kerstin Söderström sedan till Kristianstad och Knislinge. (SDS 1.8 2003)

I denna notis kommer först det vanliga: namn, ålder, hemort och anhöriga. Men i andra stycket har fokus hamnat på alla kvinnans flyttar. Notisen berättar att hon var från Dalarna, drev ett kafé, men framför allt att hon flyttade många gånger i sitt liv. Texten framstår som torftig; det gäller både beskrivningen av kvinnans liv och språket i texten. Den verkar inte vara redaktionellt skriven, utan bygger troligen på insänt material från en närstående utan skrivvana eller möjligen på en rutinmässig telefonintervju som redaktionen gjort med en närstående till den döda.

Nedan ska vi studera två nekrologer. Överlag är nekrologer längre och har ett personligt anslag eftersom det tillåts av redaktionerna och skribenten vanligen känner den som hyllas. Men i nekrologer som bygger på insänt material är det ändå tidningarna som ger ramarna för hur texten får se ut genom direkta anvisningar, åtminstone i större tidningar. I SDS ser de ut på följande vis:

\section{"Sakliga minnesord}

Skicka gärna in kort hållna och sakliga minnesord över avlidna för publicering på familjesidan. De skall vara undertecknade med för- och efternamn. Bifoga

telefonnummer." (SDS 4.6.2004) 
Det första exemplet på en nekrolog är undertecknad av några väninnor till den döda. [3]

\section{Nekrologer 2004}

\section{Solveig Stenberg Siffersinnad ekonom}

(1) Solveig Stenberg, född Wolff, har avlidit efter en längre tids sjukdom, 60 år gammal. Hennes närmaste är maken Karl-Gunnar (KG), sonen Kalle och Anna Stenberg, KG:s dotter i ett tidigare äktenskap, samt hennes barn Matteo och Evelina.

(2) Solveig Stenberg föddes i Stockholm, där hon tog handelsstudenten vid Frans Schartaus gymnasium. Efter studentexamen arbetade hon ett år som sekreterare i Hamburg. Åter hemma i Stockholm innehade hon olika vikariat, bland annat på Sparbanksföreningen. Det var Solveig Stenbergs intresse för siffror och hennes kunskaper i bokföring och ekonomi som styrde hennes yrkesval. År 1969 blev hon fast anställd som kamrer på Telefon \& Signal, där hon arbetade fram till 1979, då sonen Kalle föddes. Hon var hemma med honom några år men började sedan arbeta igen, först på Mostek och sedan på Hellermann Tyton i Järfälla, där hon var anställd vid sin död. Även där arbetade hon med ekonomi.

(3) Solveig var en i vårt "tjejgäng", och vi har haft mycket kul ihop under de 30-35 år vi har känt varandra och delat varandras sorger och glädjeämnen.

(4) Men nu finns vår fina, vackra och stiliga väninna inte mer. Cancern, som hon kämpade så tappert mot, tog till slut henne ifrån oss. Även om dödsbudet var väntat drabbade det oss tungt och smärtsamt just när sommaren var som vackrast och just när de flesta av oss var på semester någon annanstans än där Solveig var.

(5) Bakom Solveigs något reserverade framtoning fanns en vänlig, varm och omtänksam människa och en lojal vän. Solveig besatt dessutom en ovanlig psykisk styrka, som kom till uttryck inte minst under sjukdomstiden. Lugnt och sakligt informerade hon omgivningen om sjukdomsförloppet. När vi, hennes väninnor, blev ledsna över att behandlingen inte hade hjälpt fick hon dåligt samvete för att hon hade gjort oss ledsna! Solveig bevarade inte bara sin mentala styrka utan också sin skönhet in i det sista. Vår Solveig var en helt igenom vacker människa, både till det yttre och inre. Det är sådan vi kommer att minnas henne. Ewa E Blixt, Majvor Holmgren, Marianne Kristoffersson, Dagmar Schenker (DN 16.8.2004)

Textens struktur följer ett schema (jfr Labov 1972:363-370, Toolan 2001:148-161), där makrostrukturen kan skisseras på följande sätt. Först kommer en sammanfattning (abstract) i rubriken. Stycke (1) berättar om kvinnans sjukdom, död och närstående (orientering). Stycke (2) handlar om hennes skolgång och yrkesliv (komplikation). Stycke (3) berör varför detta är intressant samt kvinnornas nätverk och vänskapsrelation (värdering). Stycke (4) behandlar vad som händer nu (resultat) och stycke 5 är en fördjupning av berörda aspekter (upplösning och värdering). Sista meningen utgör codan: "Det är sådan vi kommer att minnas henne". Därefter följer skribenternas namn. Största delen av texten fokuserar privatlivet, stycke (1) och styckena (3-5). Dessa partier är skrivna med engagemang och känsla som kommer till uttryck i många positivt värderande omdömen, främst i sista och näst sista stycket, t.ex. "nu finns vår fina, vackra och stiliga väninna inte mer".

Den andra nekrologen är skriven av en arbetskamrat till den döde. Texten har ett personligt anslag men ett annat perspektiv än föregående text.

Lennart Ekelund har avlidit som tidigare meddelats.

(1) Lennart Ekelund anställdes 1973 som direktör i dåvarande Bankinspektionen med placering på dess kreditavdelning. Han hade då avslutat en karriär inom banksektorn.

(2) Med sina gedigna insikter i bankarbetet blev Lennart en värdefull förstärkning av inspektionens personal. Kreditavdelningens huvudsakliga ansvarsområde var då övervakning av kreditinstitutens kreditportföljer, något som ställde stora krav på kunskaper om kreditbedömning och om näringslivets utveckling i syfte att kunna bedöma de risker som instituten kunde utsättas för. Samtidigt innebar bankernas etableringar utomlands och 
samarbetet med tillsynsmyndigheter i andra länder ett helt nytt verksamhetsområde för kreditavdelningen.

(3) Det var alltså en turbulent tid som började under Lennarts första år i inspektionen med en hel del nya arbetsuppgifter att sätta sig in i och Lennart grep sig an arbetet med stor entusiasm. Lennart visade sin förmåga att snabbt axla de nya arbetsuppgifterna. Han hade också ambitionen att dela med sig av sina insikter och blev ett starkt stöd för sina medarbetare. Även i mindre formella sammanhang hade Lennart förmåga att sprida glädje och trevnad omkring sig och till det bidrog hans starka intresse för konst och musik.

(4) Vi som samarbetade med Lennart kommer att minnas honom som en gediget kunnig kollega och som en verklig gentleman.

Stig Danielsson (DN 12.8.2004)

Texten följer i stort samma textstruktur som den föregående med abstract i rubriken och första meningen, orientering i stycke (1), dock utan att nämna den dödes anhöriga. I stycke (2) följer händelsekedjan, komplikationen och stycke (3) har en värdering: "grep sig an arbetet med stor entusiasm ... att snabbt axla de nya arbetsuppgifterna". Texten avslutas med en coda med värdering och därefter följer skribentens namn. Till skillnad från nekrologen om kvinnan uppehåller denna sig mest vid den hyllades verksamhet på arbetsplatsen på ett uppskattande sätt. Texten kan vara svår att ta till sig för en oinsatt som inte kan förväntas förstå den i en djupare mening eftersom den innehåller en del fackord, t.ex. "kreditinstitutens kreditportföljer ... tillsynsmyndigheter i andra länder".

Karriärbeskrivningen genomsyrar i stort sett hela texten, och privatlivet berörs bara kortfattat i en enda mening: "Även i mindre formella sammanhang hade Lennart förmåga att sprida glädje och trevnad omkring sig och till det bidrog hans starka intresse för konst och musik".

Att dessa två nekrologer skiljer sig åt kan delvis ha med skribentperspektiv att göra. I första texten skriver väninnor och därför kommer privatlivet i förgrunden. I den andra skriver en arbetskamrat och då hamnar yrkeslivet i fokus. Men det är kanske bara en del av förklaringen. En annan kan vara att i den första skriver kvinnor om en kvinna och i den andra skriver en man om en man. Kanske är det så att kvinnor och män har olika uppfattning om vad som bör stå i en nekrolog.

Textschemat över hyllningar skulle på ett tentativt sätt kunna skisseras på följande vis:

1. Abstract: introduktion av huvudhändelsen födelsedag, dödsfall

2. Bakgrundsorientering: namn, ålder, hemort, ev. släktingar

3. Händelsekedja: levnadslopp, meritförteckning

4. Värdering: nätverk, relationer till andra människor och institutioner

5. Ev. fördjupning av berörda aspekter: episod (anekdot) ur den hyllades liv

6. Resultat: vad händer nu? Vi hyllar, firar eller sörjer

7. Avslutning (coda), upplösning eller värdering: hur högtidsdagen firas alt. vem som sörjer

De undersökta texterna brukar åtminstone innehålla två eller flera av följande element (jfr Labov 1972:363-370, Toolan 2001:148-149). Texterna kan strukturellt byggas upp av narrativa, deskriptiva, explikativa sekvenser som i sin tur innehåller propositioner. Om de diskuterade texternas makrostruktur ska kategoriseras som narrativ eller deskriptiv är svårt att avgöra eftersom det oftast finns inslag av både berättelse och beskrivning i texterna. En slutsats som jag kan dra är att det generellt sett finns fler deskriptiva sekvenser i texter om kvinnor och fler narrativa sekvenser i texter om män.

Avslutningsvis vill jag presentera en annorlunda nekrolog:

\section{MINNESORD}

\section{Anders Lindblad, Lund}

\section{Konstnär såg livets absurditet}

Konstnären och reklammannen Anders Lindblad, 59 år, Lund, har avlidit. Hans närmaste är barnen Jonas och Karin. 
Anders Artist - blott alltför väl minns vi nu hans anekdot om hur han för något decennium sedan, boende på Filippavägen, trodde sig ha fått ett allvarligt hjärtfel och därför ringde efter en taxi för att uppsöka vård. När han under plågor asat sig in i bilen, där en honom inte obekant chaufför visade sig sitta vid ratten, beordrade han omedelbar transport till akuten. Föraren övervägde situationen och ställde efter något ögonblick den berömda frågan "Grand eller Storkällaren?" Efter övertalning lyckades Anders få honom att köra till lasarettet. Det hela visade sig vara ett skrämskott.

Den här gången var det på riktigt och i skymningsvinden kan vi om vi lyssnar noga höra Anders på sin helsingborgska travestera: "Ryktet om min död är inte det minsta överdrivet." Nådd av dödsbudet den första april råkade någon av oss en kort stund i beråd om sanningshalten.

Anders förlorade oss för tidigt. Obetänksamt hade vi räknat med honom länge än som understrykare av livets absurditet, betonare av den intellektuella livshållningen och inte minst som dramatiskt rollgestaltande berättare. Anders behärskade både gyckleri, jazztrumslageri, måleri och skrivet ord. Det sista kanske av störst nytta inom hans på senare år lyckosamma verksamhet som ad i hälftenägt företag, World Wide Advertising, Malmö.

\section{Claes Wahlöö}

för förlorade vänner (SDS 4.6.2004)

Detta är en ovanlig nekrolog som är skriven för att hylla men också för att underhålla. Den har inte mycket av den traditionella biografin över sig, som vi sett exempel på ovan. Personen som hyllas framtonar som kul och excentrisk. Dessutom har texten skönlitterära stildrag och är påfallande välskriven. Så här avvikande från den vanliga mallen kan ibland nekrologer om män se ut, men sällan nekrologer om kvinnor. Texten ovan ligger inom den tradition som finns i The Daily Telegraph Book of Obituaries. A Celebration of Eccentric Lives av Hugh Messingberd (1995). Messingbred är en brittisk familjeredaktör som samlat roliga och småelaka nekrologer och givit ut dem i antologier. Texterna i dessa framstår som regelrätt underhållningsläsning.

\section{Avslutande sammanfattning}

Sammanfattningsvis kan sägas att familjesidan är en hierarkisk och förhållandevis manligt dominerad diskurs (jfr Stuart 1999:148), och genus i texterna konstrueras för det mesta på ett häpnadsväckande traditionellt sätt fortfarande. Det finns alltså en uppdelning i offentligt och privat, känsla och förnuft, där kvinnors liv skrivs som om de företrädesvis utspelade sig i den privata sfären med en betoning av deras inre liv och relationen till andra, medan mäns liv skrivs som de utspelade sig i en förnuftsbaserad offentlighet. Texterna om kvinnor fokuserar på hur de hyllade är och texterna om män på vad de är. Kvinnor får stå tillbaka för män i texterna; detta gäller både volymmässigt och stilmässigt, eftersom studien visar att texterna om män för det mest är längre, informationstätare och stilistiskt elegantare.

Perspektivet i texterna är beroende av vilken relation skribenten har eller har haft till den person som skildras. Texterna kan vara opersonliga eller sakligt neutrala men också personliga, affektiva och skrivna med mycket engagemang. Men texterna på familjesidorna har alltid en viss grad av formalitet annars hade de inte publicerats. Detta har med textsamspel och normsamspel att göra.

Det är viktigt att komma ihåg att bilden av verkligheten i en tidningstext och verkligheten i sig inte är identiska, men också att den redigerade verkligheten i våra medier trots allt påverkar vårt tänkande. Att det ser ut så här på familjesidan har att göra med tidningarnas texttraditioner, skribenterna, mottagarna och samhället i stort. Även om de enskilda texterna skildrar individer så är det gemensamma att både kvinnor och män framstår som kategorier, och dessa kategorier blir synliga först vid en analys av många texter. Då först framträder mönstret tydligt.

Svaret på frågan om familjesidan speglar den kvinnliga underordningen i samhället kan 
tveklöst besvaras med ett ja. På samma gång reflekteras tydligt i detta nyhetsutrymme en manlig överordning. Familjesidan speglar verkligheten såtillvida att män och mäns liv uppenbarligen anses mer värda att berätta mycket om. En annan förklaring till att det ser ut som det gör är att tidningarna har uppmuntrat skildringar av personers plats i det offentliga livet. Som världen sett ut och fortfarande ser ut blir då texter om män med nödvändighet fler och längre eftersom män finns och syns mer i det offentliga än kvinnor. Män anses på ett mer eller mindre medvetet plan viktigare. Men någon borde också ha opponerat sig mot denna ordning. Tidningarna publicerar trots allt vad konsumenterna betalar för att läsa. Analysen säger således något viktigt om den förhärskande synen på kvinnligt och manligt i texterna, hos skribenterna men även hos läsarna.

\section{(C) Gunilla Byrman}

\section{Litteratur}

Byrman, Gunilla \& Hultén, Britt (2003): "'Varför många företagsledare bär damunderkläder': Diskussion om genus och sakprosa." I Teoretiska perspektiv på sakprosa, red. Boel Englund \& Per Ledin. Lund: Studentlitteratur.

Byrman, Gunilla (2002): "Mångkulturellt och harmoniskt på familjesidan?" I HumaNetten

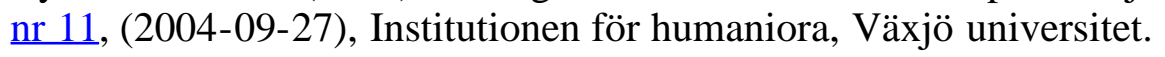

Fairclough, Norman (1992): Discourse and social change. Cambridge: Polity Press.

Hellspong, Lennart \& Ledin, Per (1997): Vägar genom texten. Handbok i brukstextsanalys. Lund: Studentlitteratur.

Hirdman, Yvonne (1988): "Genussystemet - reflexioner kring kvinnors sociala underordning". I: Kvinnovetenskaplig tidskrift nr 3. S. 49-63.

Hirdman, Yvonne (1998): "Kvinnorna i välfärdsstaten". I: Kvinnohistoria. Om kvinnors villkor från antiken till våra dagar. Stockholm. S. 203-218.

Labov, William (1972): Language in the Inner City. Philadelpia: University of Pennsylvania Press.

Stuart, Allan (1999): News Culture. Issues in Cultural and Media Studies. Buckingham, Philadelphia: Open University Press.

Toolan, Michael (2001): Narrative a Critical Linguistic Introduction. Second edition. Routledge: London and New york.

[1] Följande 10 dagar har excerperats:

Dagens Nyheter: 29, 31 juli, 1, 2, 4, 6, 7, 9, 10, 11 augusti.

Sydsvenska Dagbladet: 28, 29, 30 juli, 2, 3, 4, 6, 7, 8, 9 augusti.

Smålandsposten: 28, 29, 30, 31 juli, 3, 4, 5, 6, 7, 9 augusti.

[2] Siffrorna ger en indikation om hur det ser ut. Men förmodligen är män generellt sett överrepresenterade i högre grad. På Dagens Nyheters webbplats var nekrologerna skrivna under augusti i år 78 \% för män och 22 \% för kvinnor.

[3] Siffrorna inom parentes i texterna nedan har jag satt dit för att särskilja styckena. 